\title{
Synthesis and Characterization of a New Unsymmetrical Potentially Pentadentate Schiff Base Ligand and Related Complexes with Manganese(II), Nickel(II), Copper(II), Zinc(II) and Cadmium(II)
}

\author{
Ahmad Ali Dehghani-Firouzabadi* and Sakineh Firouzmandi \\ Department of Chemistry, Faculty of Science, Yazd University, 89195-741 Yazd, Iran
}

\begin{abstract}
New unsymmetric thioether Schiff base amine, 2-(2-aminoethylthio)- $N$-(thiophene-2ylmethylene)aniline was prepared by reaction of 2 -aminothiophenol with $N$-(2-bromoethyl) phthalimide and then by thiophene-2-carbaldehyde. Then, the phthalimide group converted to the amine by hydrazine hydrate. The new potentially pentadentate $\mathrm{N}_{3} \mathrm{~S}_{2}$ donor unsymmetrical Schiff base ligand, 2-(2-(pyridine-2-ylmethyleneamino)ethylthio)- $N$-(thiophene-2-ylmethylene) aniline (L) was prepared via $[1+1]$ condensation of pyridine-2-carbaldehyde with this amine. Manganese(II), nickel(II), copper(II), zinc(II) and cadmium(II) complexes of this ligand were prepared by adding metal salts to an ethanolic solution in this ligand. The thioether amine, ligand (L) and unsymmetric Schiff base complexes are characterized by the appropriate spectroscopic methods such as infrared (IR), UV-Vis, ${ }^{1} \mathrm{H}$ nuclear magnetic resonance (NMR), ${ }^{13} \mathrm{C}$ NMR studies, X-ray, microanalysis and mass spectrometry.
\end{abstract}

Keywords: $\mathrm{N}_{3} \mathrm{~S}_{2}$ donor, pentadentate ligand, unsymmetrical ligand, Schiff base complexes, thioether ligand

\section{Introduction}

Transition metal complexes with thioether Schiff base ligands have been prepared since the beginning of the development of coordination chemistry and there is continuing interest in these complexes. ${ }^{1,2}$ Sulfur atom coordinates to the metals through one (terminal) or both (bridging) of the lone pairs, the latter being less common. They usually form strong bonds with soft metals and more rarely with hard ones. They are considered both poor $\sigma$-donor and poor $\pi$-acceptor ligands, the latter involving the $\sigma^{*}$ orbitals of the $\mathrm{S}-\mathrm{X}$ bonds. This $\pi$-acceptor character can contribute to the $\mathrm{M}-\mathrm{S}$ bond strength. ${ }^{3}$ The synthesis of transition metal complexes of unsymmetrical Schiff bases ligands with the hard and soft atom is an important area of study with implications in bioinorganic chemistry, ${ }^{4-6}$ catalysis $^{7}$ and medical chemistry. ${ }^{8}$ Most of these unsymmetrical ligands and related complexes are Schiff bases obtained by the condensation of different types of amines with various ketones and aldehydes, and many of these in turn are multidentate ligands. ${ }^{5,-13}$ Unsymmetrical linear pentadentate Schiff base ligands that have $\mathrm{N}_{3} \mathrm{~S}_{2}$

*e-mail: aadehghani@yazd.ac.ir donors or have thiophene and pyridine groups in their structure are very rare.

Here we report the synthesis of new unsymmetric linear pentadentate Schiff base ligand and their chelates with some transition metal ions, e.g., manganese(II), nickel(II), copper(II), zinc(II) and cadmium(II).

\section{Experimental}

\section{Chemical and starting materials}

2-Aminothiophenol, pyridine-2-carbaldehyde and thiophene-2-carbaldehyde were purchased from Merck and used as received. Other reagents and solvents were of analytical grade and purchased commercially.

Instrumentation

Elemental analyses were performed in a CHNS-O-2400 II PerkinElmer. Infrared spectra were recorded in ATR, using a Bruker FT-IR Equinax-55 spectrophotometer (4000-400 $\mathrm{cm}^{-1}$ ). Mass spectrometry (MS) spectra were obtained using a QP-1100EX Shimadzu GC-MS (EI at $70 \mathrm{eV}$ ). ${ }^{1} \mathrm{H}$ and ${ }^{13} \mathrm{C}$ nuclear magnetic resonance (NMR) spectra were taken in $\mathrm{CDCl}_{3}$ or DMSO- $d_{6}$ 
on a Bruker NMR 500 and $400 \mathrm{MHz}$ spectrometer using $\mathrm{Si}\left(\mathrm{CH}_{3}\right)_{4}$ as an internal standard. The electronic spectra were taken in GBC UV-Visible Cintra 101 spectrophotometer with $1 \mathrm{~cm}$ quartz, in the range of $200-1100 \mathrm{~nm}$ at $25^{\circ} \mathrm{C}$.

\section{X-ray crystal structure determination}

Single crystal of 2-(2-(2-((thiophene-2-yl) methyleneamino)phenylthio)ethyl) isoindoline-1,3-dione suitable for X-ray analyses was obtained by evaporation of ethanolic solution of the reaction mixture at $298 \mathrm{~K}$. The details of the X-ray crystal data and of the structure solution and refinement are given in Table 1. The X-ray diffraction measurements were made on a STOE IPDS-2T diffractometer with graphite monochromated Mo K $\alpha$ radiation $(\lambda=0.71073 \AA)$. Cell constants and an orientation matrix for data collection were obtained by least-squares refinement of diffraction data from 4873 unique reflections. The structure was solved by direct methods and refined on $\mathrm{F}^{2}$ by a full-matrix least-squares procedure using anisotropic displacement parameters for all non-hydrogen atoms. The hydrogen atoms were located in their calculated positions and refined using a riding model.

Synthesis of the 2-(2-aminoethylthio)- $\mathrm{N}$-(thiophene2-ylmethylene)aniline

2-Aminothiophenol ( $6.25 \mathrm{~g}, 50 \mathrm{mmol})$ was dissolved in acetonitrile $(40 \mathrm{~mL})$ and $\mathrm{K}_{2} \mathrm{CO}_{3}(6.9 \mathrm{~g}, 50 \mathrm{mmol})$ was added. The mixture was refluxed and then a solution of $N$-(2-bromoethyl)phthalimide $(12.65 \mathrm{~g}, 50 \mathrm{mmol})$ in acetonitrile $(40 \mathrm{~mL})$ was added. The mixture was refluxed for $8 \mathrm{~h}$ and then filtered hot. ${ }^{9}$ The filtrate was reduced to dryness by rotary evaporation. The resulting product was dissolved in ethanol $(40 \mathrm{~mL})$ and thiophene-2-carbaldehyde $(5.6 \mathrm{~g}, 50 \mathrm{mmol})$ was added. After this time the solution was slowly evaporated to small volume (ca. $5 \mathrm{~mL}$ ) and cooled in refrigerator for several hours. The crystals of 2-(2-(2-((thiophene-2-yl)methyleneamino)phenylthio) ethyl)isoindoline-1,3-dione were filtered off (Scheme 1). Infrared (IR) (ATR) $v / \mathrm{cm}^{-1} 1769,1707,1610,751$. Then the methanol $(50 \mathrm{~mL})$ and hydrazine hydrate $80 \%(4 \mathrm{~mL})$ was added. The mixture was refluxed for $8 \mathrm{~h}$ and cooled in refrigerator for several hours and then filtered. The methanol were removed by rotary evaporation to leave brown oil (Scheme 1). Yield: $7.3 \mathrm{~g}(56 \%)$. IR (ATR) $\mathrm{v} / \mathrm{cm}^{-1}$ 3340, 3172, 1607, 750; ${ }^{1} \mathrm{H}$ NMR (400.1 $\mathrm{MHz}, \mathrm{CDCl}_{3}$ ) $\delta 2.86$ (s, $4 \mathrm{H}, \mathrm{CH}_{2} \mathrm{CH}_{2}$ ), 2.9-3.2 (br, $2 \mathrm{H}, \mathrm{NH}_{2}$ ), 6.68-7.82 $(\mathrm{m}, 7 \mathrm{H}, \mathrm{Ar}-\mathrm{H}), 8.79(\mathrm{~s}, 1 \mathrm{H}, \mathrm{CH}=\mathrm{N}) ;{ }^{13} \mathrm{C}$ NMR $(400.1 \mathrm{MHz}$, $\left.\mathrm{CDCl}_{3}\right) \delta 38.1,40.8,115.1,115.2,116.8,118.6,127.9$, 130.1, 130.9, 131.7, 132.6, 148.5, 155.8; EI-MS m/z, calcd. for $\mathrm{C}_{13} \mathrm{H}_{14} \mathrm{~N}_{2} \mathrm{~S}_{2}[\mathrm{M}]^{+}:$262.39, found: 262 .
Table 1. Crystal data and structure refinement for 2-(2-(2-((thiophene2-yl)methyleneamino)phenylthio)ethyl)isoindoline-1,3-dione

\begin{tabular}{|c|c|}
\hline Empirical formula & $\mathrm{C}_{21} \mathrm{H}_{16} \mathrm{~N}_{2} \mathrm{O}_{2} \mathrm{~S}_{2}$ \\
\hline Formula weight & 392.50 \\
\hline Temperature / K & $120(2)$ \\
\hline Wavelength / $\AA$ & 0.71073 \\
\hline Crystal system, space group & monoclinic, $P 2_{1} / c$ \\
\hline \multirow[t]{3}{*}{ Unit cell dimensions } & $a=7.4333(15) \AA$ \\
\hline & $\mathrm{b}=10.782(2) \AA \quad \beta=94.57(3)^{\circ}$ \\
\hline & $c=22.656(5) \AA$ \\
\hline Volume / $\AA^{3}$ & $1810.0(6)$ \\
\hline $\mathrm{Z}$, calculated density / $\left(\mathrm{mg} \mathrm{m}^{-3}\right)$ & $4,1.440$ \\
\hline Absorption coefficient $/ \mathrm{mm}^{-1}$ & 0.314 \\
\hline $\mathrm{F}(000)$ & 816 \\
\hline Crystal size / mm & $0.43 \times 0.4 \times 0.2$ \\
\hline $\begin{array}{l}\text { Theta range for data collection / } \\
\text { degree }\end{array}$ & 2.09 to 29.15 \\
\hline Limiting indices & $\begin{array}{c}-10 \leq \mathrm{h} \leq 10 \\
-14 \leq \mathrm{k} \leq 14 \\
-31 \leq 1 \leq 30\end{array}$ \\
\hline Reflections collected/unique & $20259 / 4873$ \\
\hline $\mathrm{R}$ (int) & 0.0705 \\
\hline Completeness to theta 29.15 / \% & 99.8 \\
\hline Absorption correction & none \\
\hline Refinement method & full-matrix least-squares on $\mathrm{F}^{2}$ \\
\hline Data/restraints/parameters & $4873 / 0 / 262$ \\
\hline Goodness-of-fit on $\mathrm{F}^{2}$ & 1.107 \\
\hline Final $R$ indices $[I>2 \sigma(I)]$ & $\mathrm{R}_{1}=0.0550, \mathrm{wR}_{2}=0.0964$ \\
\hline $\mathrm{R}$ indices (all data) & $\mathrm{R}_{1}=0.0762, \mathrm{wR}_{2}=0.1029$ \\
\hline Largest diff. peak and hole / (e. $\left.\AA^{-3}\right)$ & 0.298 and -0.302 \\
\hline
\end{tabular}

Synthesis of 2-(2-(pyridine-2-ylmethyleneamino)ethylthio)$\mathrm{N}$-(thiophene-2-ylmethylene)aniline (L)

A solution of 2-(2-aminoethylthio)- $N$-(thiophene2-ylmethylene)aniline $(2.62 \mathrm{~g}, 10 \mathrm{mmol})$ in ethanol $(30 \mathrm{~mL})$ was added dropwise to a refluxing solution of pyridine-2-carbaldehyde $(1.07 \mathrm{~g}, 10 \mathrm{mmol})$ in the same solvent $(20 \mathrm{~mL})$. After refluxing for $3 \mathrm{~h}$ the solution was vacuum evaporated to yield the crude product as a yellow oil. A small volume of petroleum ether was added to the residue remaining in the flask and rubbed. Then liquid was decanted and residue was evaporated until a yellow oil remained (Scheme 2). Yield: $2.95 \mathrm{~g}(84 \%) . \lambda$ (DMF) / nm $314(\log \varepsilon=4.05), 327(\log \varepsilon=4.02) ;$ IR (ATR) $v / \mathrm{cm}^{-1}$ 1647, 1610, 748; ${ }^{1} \mathrm{H}$ NMR $\left(400.1 \mathrm{MHz}, \mathrm{CDCl}_{3}\right) \delta 3.12(\mathrm{t}$, $\left.2 \mathrm{H}, \mathrm{CH}_{2}\right), 3.81\left(\mathrm{t}, 2 \mathrm{H}, \mathrm{CH}_{2}\right), 6.53-8.39(\mathrm{~m}, 11 \mathrm{H}, \mathrm{Ar}-\mathrm{H})$, $8.63(\mathrm{~s}, 1 \mathrm{H}, \mathrm{CH}=\mathrm{N}), 8.74(\mathrm{~s}, 1 \mathrm{H}, \mathrm{CH}=\mathrm{N}) ;{ }^{13} \mathrm{C}$ NMR $\left(400.1 \mathrm{MHz}, \mathrm{CDCl}_{3}\right) \delta 35.4,60.4,115.0,118.4,120.8$, 121.6, 122.6, 123.6, 124.9, 125.3, 125.7, 126.3, 129.8, 136.2, 136.7, 149.5, 149.7, 154.2, 163.2; EI-MS m/z, calcd. for $\mathrm{C}_{19} \mathrm{H}_{17} \mathrm{~N}_{3} \mathrm{~S}_{2}[\mathrm{M}]^{+}:$351.49, found: 351 . 


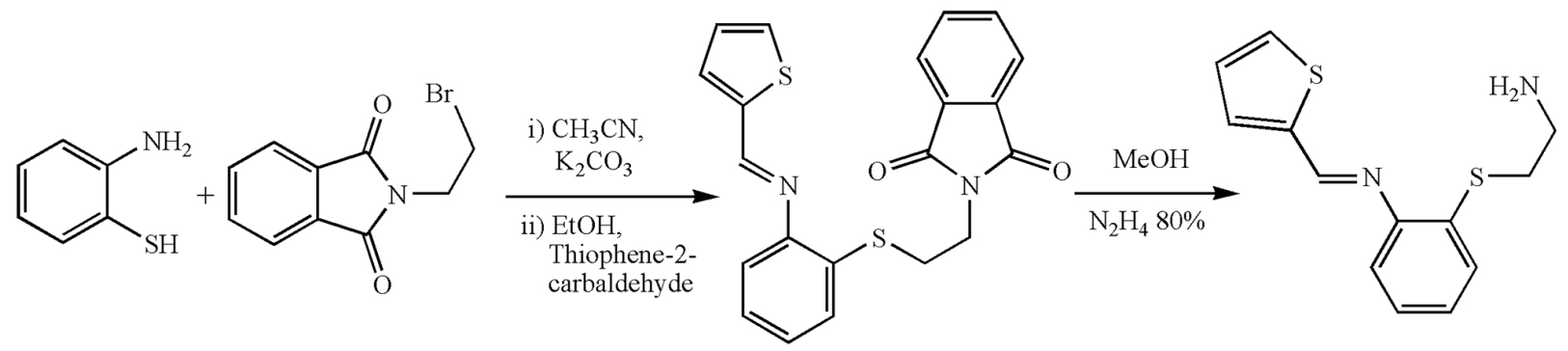

Scheme 1. Syntheses of the 2-(2-(2-((thiophene-2-yl)methyleneamino)phenylthio)ethyl) isoindoline-1,3-dione and the 2-(2-aminoethylthio)- $N$-(thiophen2-ylmethylene)aniline.

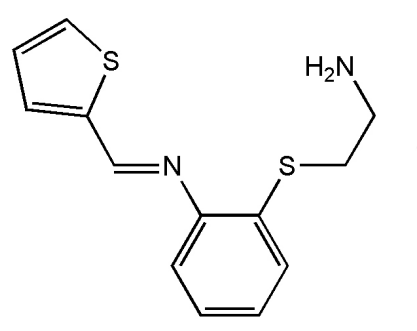<smiles>O=Cc1ccccn1</smiles>

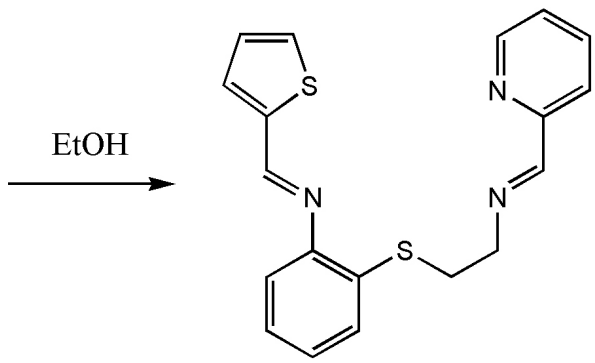

Scheme 2. Synthesis of the ligand (L).

\section{General synthesis of the complexes}

2-(2-(Pyridine-2-ylmethyleneamino)ethylthio)- $N$ (thiophene-2-ylmethylene)aniline (L) $(0.351 \mathrm{~g}, 1 \mathrm{mmol})$ was dissolved in ethanol $(10 \mathrm{~mL})$ and then a solution of metal ion $(1 \mathrm{mmol})$ in ethanol $(20 \mathrm{~mL})$ was added and the reaction mixture was refluxed for $1 \mathrm{~h}$. The solution was then concentrated in a rotary evaporator to ca. $5-10 \mathrm{~mL}$. The complexes were filtered off, washed with cold ethanol and air-dried (Scheme 3).

\section{$[\mathrm{MnL}] \mathrm{Cl}_{2} \cdot \mathrm{EtOH}$}

Yield: $392 \mathrm{mg}(75 \%)$. Anal. calcd. for $\mathrm{C}_{21} \mathrm{H}_{23} \mathrm{Cl}_{2} \mathrm{MnN}_{3} \mathrm{OS}_{2}$ : C, 48.19; H, 4.43; N, 8.03\%. Found: C, 47.36; H, 4.33; $\mathrm{N}, 8.63 \% ; \lambda$ (DMF) / nm 309 (log $\varepsilon=3.04)$; IR (ATR) $\mathrm{v} / \mathrm{cm}^{-1} 1609,751$.

$[\mathrm{NiL}] \mathrm{Cl}_{2}$

Yield: $375 \mathrm{mg}$ (78\%). Anal. calcd. for $\mathrm{C}_{19} \mathrm{H}_{17} \mathrm{Cl}_{2} \mathrm{~N}_{3} \mathrm{NiS}_{2}$ : C, 47.43; H, 3.56; N, 8.73\%. Found: C, 46.54;
$\mathrm{H}, 2.98 ; \mathrm{N}, 9.04 \% ; \lambda(\mathrm{DMF}) / \mathrm{nm} 325(\log \varepsilon=4.21)$, $533(\log \varepsilon=1.90) ;$ IR (ATR) $v / \mathrm{cm}^{-1} 1608,759$.

\section{[CuL] $\mathrm{Cl}_{2} \cdot \mathrm{CuCl}_{2}$}

Yield: $366 \mathrm{mg}$ (59\%). Anal. calcd. for $\mathrm{C}_{19} \mathrm{H}_{17} \mathrm{Cl}_{4} \mathrm{Cu}_{2} \mathrm{~N}_{3} \mathrm{~S}_{2}$ : C, 36.78; H, 2.76; N, 6.77\%. Found: C, 36.43; H, 2.81; N, $6.92 \% ; \lambda(\mathrm{DMF}) / \mathrm{nm} 312(\log \varepsilon=3.91), 550(\log \varepsilon=2.77)$; IR (ATR) $v / \mathrm{cm}^{-1} 1609,752$.

\section{$[\mathrm{ZnL}] \mathrm{Cl}_{2} \cdot 1.5 \mathrm{H}_{2} \mathrm{O}$}

Yield: $330 \mathrm{mg}(64 \%)$. Anal. calcd. for $\mathrm{C}_{19} \mathrm{H}_{20} \mathrm{Cl}_{2} \mathrm{~N}_{3} \mathrm{O}_{1.5} \mathrm{~S} 2 \mathrm{Zn}: \mathrm{C}, 44.33 ; \mathrm{H}, 3.92 ; \mathrm{N}, 8.16 \%$. Found: C, 43.93; H, 3.59; N, 8.99\%; $\lambda$ (DMF) / nm 308 $(\log \varepsilon=4.09) ;$ IR (ATR) $v / \mathrm{cm}^{-1} 3405,1627,1650,776$.

\section{$[\mathrm{CdL}] \mathrm{Cl}_{2} \cdot \mathrm{H}_{2} \mathrm{O}$}

Yield: $470 \mathrm{mg}(85 \%)$. Anal. calcd. for $\mathrm{C}_{19} \mathrm{H}_{19} \mathrm{CdCl}_{2} \mathrm{~N}_{3} \mathrm{OS}_{2}$ : C, 41.28; H, 3.46; N, 7.60\%. Found: C, 41.30; H, 3.80; N, $7.48 \% ; \lambda$ (DMF) / nm $313(\log \varepsilon=3.99) ;$ IR (ATR) $v / \mathrm{cm}^{-1}$ $3443,1605,1649,778 ;{ }^{1} \mathrm{H}$ NMR (500.1 MHz, DMSO- $\left.d_{6}\right)$<smiles>C(=N/CCSc1ccccc1/N=C/c1cccs1)\c1ccccn1</smiles>

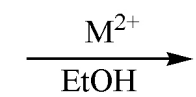

$\mathrm{M}=\mathrm{Mn}, \mathrm{Ni}, \mathrm{Cu}, \mathrm{Zn}, \mathrm{Cd}$<smiles></smiles>

Scheme 3. Synthesis of the complexes. 
$\delta 3.15$ (t, 2H, J $6.1 \mathrm{~Hz}, \mathrm{CH}_{2}$ ), 3.79 (t, $2 \mathrm{H}, J 6.1 \mathrm{~Hz}, \mathrm{CH}_{2}$ ), $5.32\left(\mathrm{~s}, 2 \mathrm{H}, \mathrm{H}_{2} \mathrm{O}\right), 6.55(\mathrm{t}, 1 \mathrm{H}, J 7.4 \mathrm{~Hz}, \mathrm{Ar}-\mathrm{H}), 6.74(\mathrm{~d}$, $1 \mathrm{H}, J 8.0 \mathrm{~Hz}, \mathrm{Ar}-\mathrm{H}$ ), 7.04 (t, 1H, J 7.3 Hz, Ar-H), 7.29 (d, $1 \mathrm{H}, J 7.5 \mathrm{~Hz}, \mathrm{Ar}-\mathrm{H}), 7.81$ (t, 1H, J 6.1 Hz, Ar-H), 7.99 (d, 1H, J 7.5 Hz, Ar-H), 8.22 (t, 1H, J 7.4 Hz, Ar-H), 8.57 (s, $1 \mathrm{H}, \mathrm{CH}=\mathrm{N}), 8.80(\mathrm{~d}, 2 \mathrm{H}, J 4.3 \mathrm{~Hz}, \mathrm{Ar}-\mathrm{H}), 7.25(J 4.1 \mathrm{~Hz})$ and $7.58(J 7.2 \mathrm{~Hz})(\mathrm{t}, 1 \mathrm{H}, \mathrm{Ar}-\mathrm{H}), 7.71(J 3.2 \mathrm{~Hz})$ and 7.87 $(J 4.8 \mathrm{~Hz})(\mathrm{d}, 1 \mathrm{H}, \mathrm{Ar}-\mathrm{H}), 8.07(\mathrm{~J} 7.7 \mathrm{~Hz})$ and $8.76(\mathrm{~J} 4.2 \mathrm{~Hz})$ $(\mathrm{d}, 1 \mathrm{H}, \mathrm{Ar}-\mathrm{H}), 8.63$ and $9.06(\mathrm{~s}, 1 \mathrm{H}, \mathrm{CH}=\mathrm{N}) .{ }^{13} \mathrm{C} \mathrm{NMR}$ $\left(500.1 \mathrm{MHz}, \mathrm{DMSO}-d_{6}\right) \delta 34.0,58.3,115.4,115.7,117.5$, 128.6, 129.1, 130.2, 135.9, 141.2, 150.2, 150.6, 162.5.

\section{Results and Discussion}

The IR spectrum for 2-(2-(2-((thiophene-2-yl) methyleneamino)phenylthio)ethyl) isoindoline-1,3dione shows bands at 1769 and $1707 \mathrm{~cm}^{-1}$ assignable to the carbonyl groups $(\mathrm{C}=\mathrm{O})$ in phthalimide, band at $1610 \mathrm{~cm}^{-1}$ assignable to the imine stretch and a band at $751 \mathrm{~cm}^{-1}$ due to the thioethers stretch. The IR spectrum for 2-(2-aminoethylthio)- $N$-(thiophene-2-ylmethylene) aniline shows bands at 3340 and $3172 \mathrm{~cm}^{-1}$ assignable to the aliphatic primary amine vibrations $\left(\mathrm{NH}_{2}\right)$, band at $1607 \mathrm{~cm}^{-1}$ assignable to the imine stretch and a band at $750 \mathrm{~cm}^{-1}$ due to the thioethers stretch. The IR spectrum for the ligand (L) confirms the presence of two different imines (1647 and $1608 \mathrm{~cm}^{-1}$ ) and the absence of carbonyl and amine functional groups of the starting materials. In these compounds, the imine stretch band shifts to lower wave number $\left(1607-1610 \mathrm{~cm}^{-1}\right)$ which supports overlapped resonances of the imine bond with the phenyl and thiophene rings. The vibration peak of $\mathrm{C}-\mathrm{S}$ is observed in $748 \mathrm{~cm}^{-1}$. In the IR spectra of manganese(II), nickel(II) and copper(II) complexes, the band at about 1608 or $1609 \mathrm{~cm}^{-1}$ and in the IR spectra of zinc(II) and cadmium(II) complexes, the bands in the range of $1605-650 \mathrm{~cm}^{-1}$ are associated with $v(\mathrm{C}=\mathrm{N})$ vibration and the vibration peaks of $\mathrm{C}-\mathrm{S}$ are observed in the range of $751-778 \mathrm{~cm}^{-1}$. The vibration peaks of $\mathrm{C}=\mathrm{N}$ and $\mathrm{C}-\mathrm{S}$ are shifted relative to the similar bands of the ligand that show the imine nitrogen atoms and the thioether sulfur atom coordinated to the metal ions. ${ }^{14-16}$

${ }^{1} \mathrm{H}$ and ${ }^{13} \mathrm{C}$ NMR results obtained for prepared compounds at ambient temperature in $\mathrm{CDCl}_{3}$ and DMSO- $d_{6}$, respectively, are presented in Experimental section. The ${ }^{1} \mathrm{H}$ and ${ }^{13} \mathrm{C}$ NMR spectra of the 2-(2-aminoethylthio)$N$-(thiophene-2-ylmethylene)aniline indicate that this compound has synthesized. The slightly broad signal at 2.9-3.2 ppm in the ${ }^{1} \mathrm{H}$ NMR spectrum of this Schiff base amine is assigned to the $\mathrm{NH}_{2}$ protons and the $v(\mathrm{CH}=\mathrm{N})$ proton exhibits a singlet resonance at $8.79 \mathrm{ppm}$.
The ${ }^{1} \mathrm{H}$ NMR spectrum exhibits a singlet at $2.86 \mathrm{ppm}$ corresponding to the methylen protons and the resonances for the aromatic rings (phenyl and thiophene) protons are observed in the region of 6.68-7.82 ppm. In the ${ }^{13} \mathrm{C}$ NMR spectrum of this Schiff base amine, azomethine carbon resonance is observed in the $155.8 \mathrm{ppm}$ and the resonances for the aliphatic $\mathrm{C}-\mathrm{N}$ and $\mathrm{C}-\mathrm{S}$ carbon atoms are observed in the 38.1 and $40.8 \mathrm{ppm}$, respectively. The aromatic carbons of the benzyl and thiophene rings are observed in the 115.1-148.5 ppm range. The ${ }^{1} \mathrm{H}$ NMR spectrum of ligand $(\mathrm{L})\left({ }^{1} \mathrm{H}\right.$ and ${ }^{13} \mathrm{C}$ NMR spectra of ligand show amount of impurity due to its instability), shows the aliphatic protons in the region of 3.12-3.81 ppm, the aromatic ring protons in the region of 6.53-8.39 ppm and the $v(\mathrm{CH}=\mathrm{N})$ protons in the 8.63 and $8.74 \mathrm{ppm}$. The ${ }^{13} \mathrm{C}$ NMR spectrum of ligand features 2 signals for the aliphatic carbon atoms and 15 signals for the aromatic carbon atoms in the region of 35.4-149.7 ppm. In this spectrum, azomethine carbons are observed in the 154.2 and $163.2 \mathrm{ppm}$.

For the cadmium(II) complex, we propose two conformation isomer $\mathrm{Z}$ and $\mathrm{E}$ for this complex (Figure 1). $\mathrm{Z}$ and $\mathrm{E}$ configurations would be expected to lead to two separate resonances in the ${ }^{1} \mathrm{H}$ NMR spectrum for the thiophene ring and imine group attached to it. The ${ }^{1} \mathrm{H}$ NMR spectrum (Figure 2) of the cadmium(II) complex confirm this two isomer in E/Z ratio approximately $70 / 30$. The ${ }^{1} \mathrm{H}$ NMR spectrum of this complex shows two signals at 7.71 and $7.81 \mathrm{ppm}$ corresponding to the imine proton $\left(\mathrm{H}_{1}\right.$ in $\mathrm{Z}$ and $\mathrm{E}$ ). The thiophene protons appear as two triplets at 7.25, $7.58 \mathrm{ppm}\left(\mathrm{H}_{\mathrm{n}}\right.$ in $\mathrm{Z}$ and $\left.\mathrm{E}\right)$ and four doublets at 7.71, 7.87 ppm $\left(\mathrm{H}_{\mathrm{m}}\right.$ in $\mathrm{Z}$ and $\left.\mathrm{E}\right)$ and 8.07, $8.76 \mathrm{ppm}\left(\mathrm{H}_{\mathrm{o}}\right.$ in $\mathrm{Z}$ and $\mathrm{E}$ ). It was not possible to assign these resonances unambiguously to individual two-conformation isomer $\mathrm{Z}$ and $\mathrm{E}$ for this complex directly from the spectrum. However, it should be noted, that the sulfur atom of thiophene in conformation isomer $\mathrm{E}$ can be coordinated to the $\mathrm{Cd}$ and the resulted signals (thiophene ring and imine group attached to it) moved downfield. Also, the ${ }^{1} \mathrm{H}$ NMR spectrum of this complex shows two triplet signals due to the methylene protons $\left(\mathrm{H}_{\mathrm{f}}\right.$ and $\left.\mathrm{H}_{\mathrm{g}}\right)$ at 3.15 and $3.79 \mathrm{ppm}$, and also shows a signal at $5.32 \mathrm{ppm}$, corresponding to coordinated $\mathrm{H}_{2} \mathrm{O} .{ }^{17}$ The pyridine protons appear as two triplets at 7.81, 8.22 ppm $\left(\mathrm{H}_{\mathrm{b}}, \mathrm{H}_{\mathrm{c}}\right)$ and two doublets at 7.99, $8.80 \mathrm{ppm}\left(\mathrm{H}_{\mathrm{d}}, \mathrm{H}_{\mathrm{a}}\right)$, and the benzene ring protons appear as two triplets and two doublets at $6.55,7.04 \mathrm{ppm}\left(\mathrm{H}_{\mathrm{j}}\right.$, $\left.\mathrm{H}_{\mathrm{i}}\right)$ and 6.74, $7.29 \mathrm{ppm}\left(\mathrm{H}_{\mathrm{k}}, \mathrm{H}_{\mathrm{h}}\right)$, respectively. The singlet at $8.57 \mathrm{ppm}$ (which is shifted upfield) corresponds to the imine proton $\left(\mathrm{H}_{\mathrm{e}}\right) \cdot{ }^{18} \mathrm{In}$ the ${ }^{13} \mathrm{C}$ NMR spectrum of $[\mathrm{CdL}]^{2+}$, azomethine carbon resonances are observed at 150.2 and $162.5 \mathrm{ppm}$. Two methylene carbon atoms present in complex exhibited signals at 34.0 and $58.3 \mathrm{ppm}$ and the 


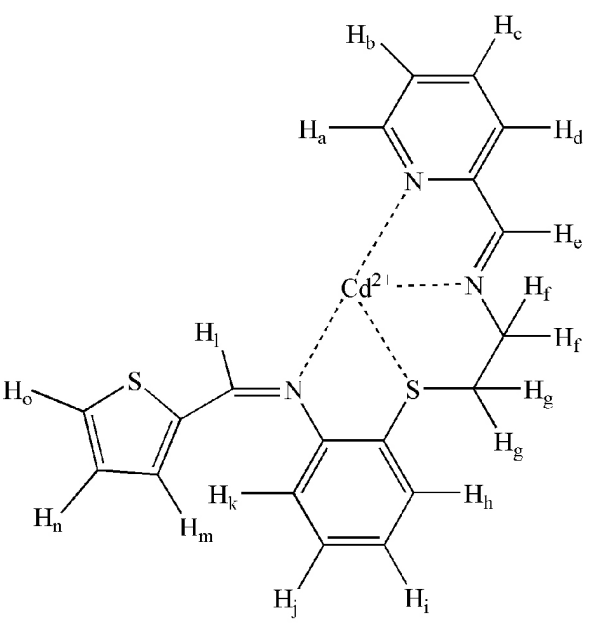

$\mathbf{Z}$

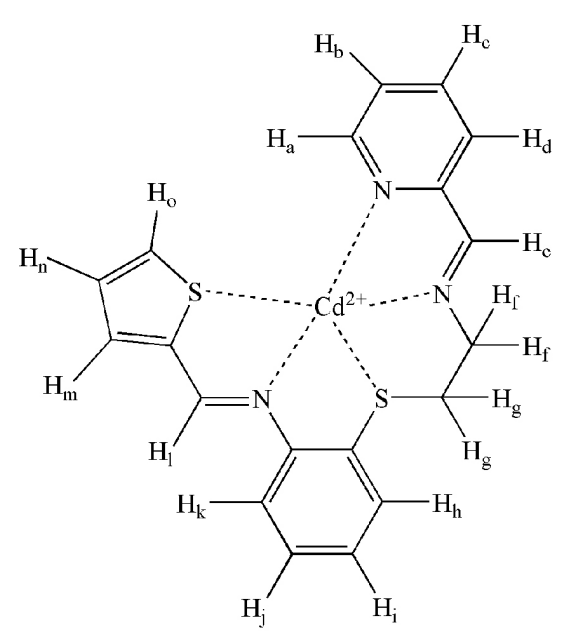

E

Figure 1. Two conformation isomer $\mathrm{Z}$ and $\mathrm{E}$ for the cadmium(II) complex.

言

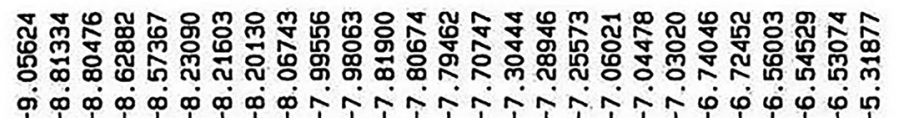

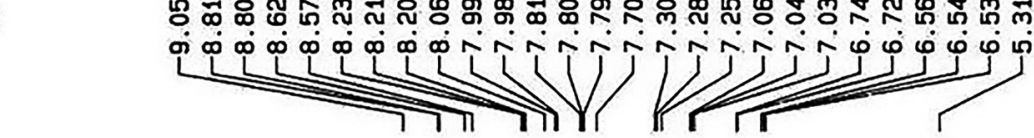

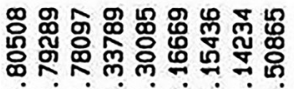

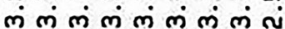<smiles>C=CCCC</smiles><smiles>C1CCCCC1</smiles>

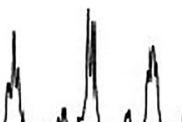<smiles>C=CCCCCCCCCCCC</smiles>

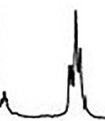

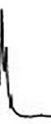<smiles>IC1=CC=C1</smiles>

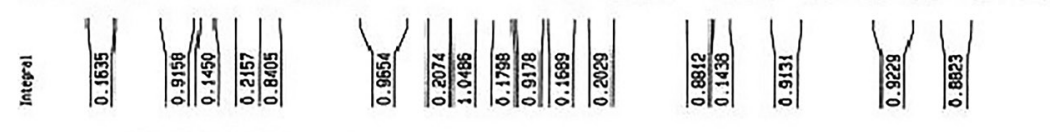

ppn 8.5

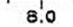

7.5

70

6.5
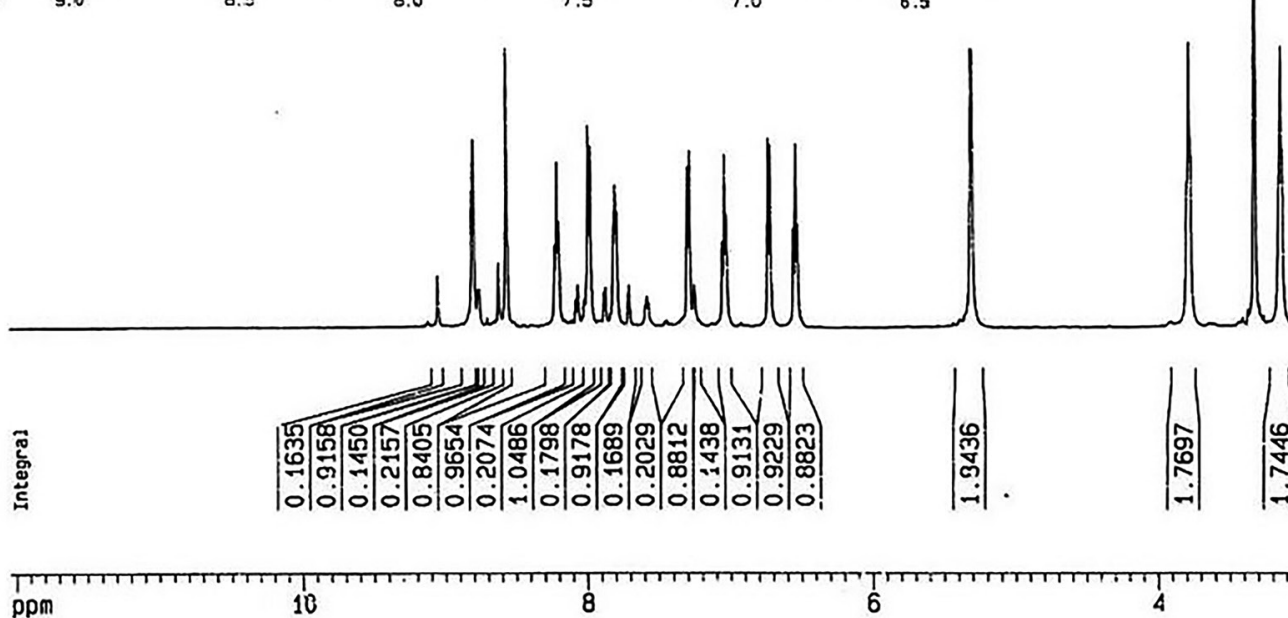

8

4

Figure 2. ${ }^{1} \mathrm{H}$ NMR spectrum of the $[\mathrm{Cd}(\mathrm{L})] \mathrm{Cl}_{2} \cdot \mathrm{H}_{2} \mathrm{O}$ in DMSO- $d_{6}$. 
resonances for the aromatic rings carbons are observed in the region 115.4-150.2 ppm.

The EI mass spectra of the 2-(2-aminoethylthio)- $N$ (thiophene-2-ylmethylene)aniline and the unsymmetrical Schiff bases ligand (L), provide strong evidence for the formation of these compounds and exhibit peaks at higher molecular weights. The peak in the spectrum of 2-(2-aminoethylthio)- $N$-(thiophene-2-ylmethylene)aniline is observed at $\mathrm{m} / \mathrm{z} 262$ and the peak in the spectrum of the ligand is observed at $\mathrm{m} / \mathrm{z} 351$ corresponding to $[\mathrm{L}]^{+}$. The absorption spectrum for $0.001 \mathrm{~mol} \mathrm{~L}^{-1}$ solutions of the ligand (L) in DMF shows two absorption bands at $314 \mathrm{~nm}$ ( $\log \varepsilon=4.05)$ and $327 \mathrm{~nm}(\log \varepsilon=4.02)$, that these bands can be attributed to $\pi \rightarrow \pi^{*}$ and $n \rightarrow \pi^{*}$ transitions. ${ }^{19}$ The absorption spectra for $0.001 \mathrm{~mol} \mathrm{~L}^{-1}$ solutions of complexes in DMF show bands at 308 to $325 \mathrm{~nm}$ corresponding to $\pi \rightarrow \pi^{*}$ transitions. In general, the electronic transitions for zinc(II), cadmium(II) $\left(\mathrm{d}^{10}\right)$ and manganese(II) $\left(\mathrm{d}^{5}\right.$ high spin) complexes are spin-forbidden and hence cannot be observed. Complex copper(II) shows only one band at $550 \mathrm{~nm}(\log \varepsilon=2.77)$ corresponding to $\mathrm{d} \rightarrow \mathrm{d}$ transition. Complex nickel(II) displayed a less intense band at $550 \mathrm{~nm}$ ( $\log \varepsilon=1.90$ ) corresponding to a forbidden $\mathrm{d} \rightarrow \mathrm{d}$ transition, which is consistent with a square planar geometry. ${ }^{20-22}$ The elemental analyses for these complexes are in good agreement with the above molecular formula. In absence of crystal structures, we must be careful in any attempt to elucidate the coordinative environment of the metal ions on these systems. Taking into account that there are five donor atoms in the ligand, it could be suggested a distorted tetrahedral or square planar environment for each metal or five coordinated geometry for manganese(II) and cadmium(II), which would be in agreement with the UV-Vis data.

\section{Description of the crystal structure}

Single crystal of 2-(2-(2-((thiophene-2-yl) methyleneamino)phenylthio)ethyl)isoindoline-1,3-dione were obtained by slow evaporation of an ethanol solution of this compound. Crystal and structure refinement data are given in Table 1, and the molecular structure is shown in Figure 3. This compound crystallizes in monoclinic system in the $P 2{ }_{1} / c$ space group with the disordered thiophene ring (with occupancies of 0.64 and 0.36 ). ${ }^{23}$ The bond lengths and angles are within the expected range of values. Selected bond lengths, bond angles and hydrogen bonds are given in Tables 2 and 3. Among the bond lengths, significant difference is observed between the aliphatic $(1.815 \AA)$ and aromatic (1.772 $\AA$ ) $\mathrm{C}-\mathrm{S}$ (thioether) bonds. The different bond lengths are observed between $\mathrm{C}(14)-\mathrm{O}(1)(1.218 \AA)$,
$\mathrm{C}(14)-\mathrm{N}(2)(1.389 \AA)$ and $\mathrm{C}(21)-\mathrm{O}(2)(1.211 \AA)$, $\mathrm{C}(21)-\mathrm{N}(2)(1.402 \AA)$. This different bond lengths shows that there is resonance between $\mathrm{N}(2)-\mathrm{C}(14)-\mathrm{O}(1)$ more than between $\mathrm{N}(2)-\mathrm{C}(21)-\mathrm{O}(2)$. The dihedral angles for $\mathrm{S}(2)-\mathrm{C}(11)-\mathrm{C}(6)-\mathrm{N}(1)$ and $\mathrm{S}(2)-\mathrm{C}(12)-\mathrm{C}(13)-\mathrm{N}(2)$ are $5.1^{\circ}$ and $72.45^{\circ}$, respectively. Each unit cell contains four molecules and each molecule is involved in intermolecular hydrogen bonding interactions with $\mathrm{C}=\mathrm{O}$ groups $[\mathrm{H}(9) \cdots \mathrm{O}(1) \# 1,2.60 \AA$; $\mathrm{H}(18) \cdots \mathrm{O}(2) \# 2,2.45 \AA$ (symmetry codes: \#1: $-\mathrm{x}+1,-\mathrm{y},-\mathrm{z} ; \# 2:-\mathrm{x}, \mathrm{y}+1 / 2$, $-z+1 / 2)]$.

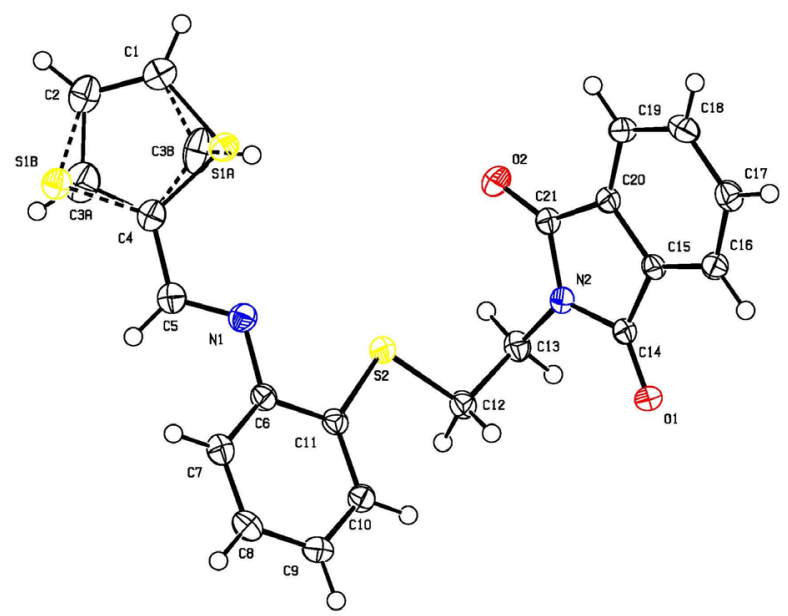

Figure 3. Crystal structure of 2-(2-(2-((thiophene-2-yl)methyleneamino) phenylthio)ethyl)isoindoline-1,3-dione showing 50\% displacement ellipsoids.

Table 2. Selected bond lengths and angles for 2-(2-(2-((thiophene-2-yl) methyleneamino)phenylthio)ethyl)isoindoline-1,3-dione

\begin{tabular}{lccc}
\hline \multicolumn{3}{c}{ Bond length / $\mathrm{c}$} & \multicolumn{2}{c}{ Bond angle / degree } \\
\hline $\mathrm{C}(11)-\mathrm{S}(2)$ & $1.772(2)$ & $\mathrm{H}(12 \mathrm{~B})-\mathrm{C}(12)-\mathrm{C}(13)-\mathrm{H}(13 \mathrm{~A})^{\mathrm{a}}$ & 73.17 \\
$\mathrm{C}(12)-\mathrm{S}(2)$ & $1.815(2)$ & $\mathrm{H}(12 \mathrm{~B})-\mathrm{C}(12)-\mathrm{C}(13)-\mathrm{H}(13 \mathrm{~B})^{\mathrm{a}}$ & 46.24 \\
$\mathrm{C}(4)-\mathrm{S}(1 \mathrm{~A})^{\mathrm{a}}$ & $1.707(3)$ & $\mathrm{S}(2)-\mathrm{C}(12)-\mathrm{C}(13)-\mathrm{N}(2)$ & $72.45(18)$ \\
$\mathrm{C}(4)-\mathrm{S}(1 \mathrm{~B})^{\mathrm{a}}$ & $1.728(4)$ & $\mathrm{S}(2)-\mathrm{C}(11)-\mathrm{C}(6)-\mathrm{N}(1)$ & $5.1(2)$ \\
$\mathrm{C}(21)-\mathrm{O}(2)$ & $1.211(2)$ & $\mathrm{C}(7)-\mathrm{C}(6)-\mathrm{N}(1)-\mathrm{C}(5)$ & $44.9(3)$ \\
$\mathrm{C}(14)-\mathrm{O}(1)$ & $1.218(2)$ & $\mathrm{N}(1)-\mathrm{C}(5)-\mathrm{C}(4)-\mathrm{S}(1 \mathrm{~A})^{\mathrm{a}}$ & $1.1(3)$ \\
$\mathrm{C}(13)-\mathrm{N}(2)$ & $1.456(2)$ & $\mathrm{C}(12)-\mathrm{S}(2)-\mathrm{C}(11)-\mathrm{C}(10)$ & $5.45(19)$ \\
$\mathrm{C}(14)-\mathrm{N}(2)$ & $1.389(2)$ & $\mathrm{C}(11)-\mathrm{S}(2)-\mathrm{C}(12)$ & $102.75(9)$ \\
$\mathrm{C}(21)-\mathrm{N}(2)$ & $1.402(2)$ & $\mathrm{C}(5)-\mathrm{N}(1)-\mathrm{C}(6)$ & $120.92(17)$ \\
$\mathrm{C}(6)-\mathrm{N}(1)$ & $1.413(3)$ & $\mathrm{C}(14)-\mathrm{N}(2)-\mathrm{C}(21)$ & $112.03(16)$ \\
$\mathrm{C}(5)-\mathrm{N}(1)$ & $1.279(3)$ & $\mathrm{O}(2)-\mathrm{C}(21)-\mathrm{C}(20)$ & $129.56(18)$ \\
\hline
\end{tabular}

${ }^{a}$ Occupancies of A: 0.64 and B: 0.36 .

\section{Conclusion}

In this work, we designed and prepared the unsymmetrical amine and then unsymmetrical potentially 
Table 3. Hydrogen bonds for 2-(2-(2-((thiophene-2-yl)methyleneamino)phenylthio)ethyl)isoindoline-1,3-dione

\begin{tabular}{lccc}
\hline $\mathrm{D}-\mathrm{H} \cdots \mathrm{A}$ & $\mathrm{D}-\mathrm{H} / \AA$ & $\mathrm{H} \cdots \mathrm{A} / \AA$ & $\mathrm{D} \cdots \mathrm{A} / \AA$ \\
$\mathrm{C}(9)-\mathrm{H}(9) \cdots \mathrm{O}(1) \# 1$ & 0.93 & 2.60 & $3.272(3)$ \\
$\mathrm{C}(18)-\mathrm{H}(18) \cdots \mathrm{O}(2) \# 2$ & 0.93 & 2.45 & $3.117(3)$ \\
\hline
\end{tabular}

Symmetry codes: \#1: $-\mathrm{x}+1,-\mathrm{y},-\mathrm{z} ; \# 2:-\mathrm{x}, \mathrm{y}+1 / 2,-\mathrm{z}+1 / 2$.

pentadentate Schiff base ligand (L) containing the pyridine and thiophene moieties and/or hard-soft donors $\left(\mathrm{N}_{3} \mathrm{~S}_{2}\right)$. Then five complexes of manganese(II), nickel(II), copper(II), zinc(II) and cadmium(II) from ligand were synthesized and characterized by various spectroscopic methods. Taking into account that there are five donor atoms in the ligand, it was found that only N3S donor set has bonding interaction (in agreement with the UV-Vis data). In the absence of crystal structures, it could be suggested a distorted tetrahedral or square planar environment for each metal or five coordinated geometry for manganese(II) and cadmium(II).

\section{Supplementary Information}

Supplementary data (FTIR, ${ }^{1} \mathrm{H}$ NMR and ${ }^{13} \mathrm{C}$ NMR spectra) are available free of charge at http://jbcs.sbq.org.br as PDF file. CCDC 916929 contains the supplementary crystallographic data for 2-(2-(2-((thiophene-2-yl) methyleneamino)phenylthio)ethyl)isoindoline-1,3dione. These data can be obtained free of charge via http://www.ccdc.cam.ac.uk/conts/retrieving.html, or from the Cambridge Crystallographic Data Centre, 12 Union Road, Cambridge CB2 1EZ, UK; fax: (+44) 1223-336-033; or e-mail: deposit@ccdc.cam.ac.uk.

\section{Acknowledgments}

We are grateful to the Faculty of Chemistry of Yazd University and Ministry of Science, Research and Technology of Iran, for financial support.

\section{References}

1. Murray, S. G.; Hartley, F. R.; Chem. Rev. 1981, 81, 365.

2. Masdeu-Bulto, A. M.; Dieguez, M.; Martin, E.; Gomez, M.; Coord. Chem. Rev. 2003, 242, 159.

3. Kraatz, H. B.; Jacobsen, H.; Ziegler, T.; Boorman, P. M.; Organometallics 1993, 12, 76.

4. Taki, M.; Hattori, H.; Osako, T.; Nagatomo, S.; Shiro, M.; Kitagawa, T.; Itoh, S.; Inorg. Chim. Acta 2004, 357, 3369.
5. Dolega, A.; Coord. Chem. Rev. 2010, 254, 916.

6. Harrop, T. C.; Mascharak, P. K.; Acc. Chem. Res. 2004, 37, 253.

7. Kwong, H. L.; Yeung, H. L.; Yeung, C. T.; Lee, W. S.; Lee, C. S.; Wong, W. L.; Coord. Chem. Rev. 2007, 251, 2188.

8. Saghatforoush, L. A.; Chalabian, F.; Aminkhani, A.; Karimnezhad, G.; Ershad, S.; Eur. J. Med. Chem. 2009, 44, 4490.

9. Dehghani-Firouzabadi, A. A.; Motevaseliyan, F.; Eur. J. Chem. 2014, 5, 635 .

10. Keypour, H.; Rezaeivala, M.; Fall, Y.; Dehghani-Firouzabadi, A. A.; Arkivoc 2009, 10, 292.

11. Saghatforoush, L. A.; Aminkhani, A.; Chalabian, F.; Transition Met. Chem. 2009, 34, 899.

12. Ezeh, V. C.; Patra, A. K.; Harrop, T. C.; Inorg. Chem. 2010, 49, 2586.

13. Chattopadhyay, S.; Ray, M. S.; Chaudhuri, S.; Mukhopadhyay, G.; Bocelli, G.; Cantoni, A.; Ghosh, A.; Inorg. Chim. Acta 2006, 359, 1367.

14. Nakamoto, K.; Infrared and Raman Spectra of Inorganic and Coordination Compounds, $3^{\text {rd }}$ ed.; John Wiley \& Sons: New York, 1978.

15. Dehghani-Firouzabadi, A. A.; Kargar, H.; Eslaminejad, S.; Notash, B.; J. Coord. Chem. 2015, 68, 4345.

16. Sarkar, S.; Dey, K.; Spectrochimica Acta, Part A 2005, 62, 383.

17. Keypour, H.; Azadbakht, R.; Salehzadeh, S.; Khanmohammadi, H.; Khavasi, H.; Adams, H.; Polyhedron 2008, 27, 1631.

18. Lindoy, L. F.; Louie, H. W.; Inorg. Chem. 1981, $20,4186$.

19. Khandar, A. A.; Cardin, C.; Hosseini-Yazdi, S. A.; McGrady, J.; Abedi, M.; Zarei, S. A.; Gan, Y.; Inorg. Chim. Acta 2010, 363,4080 .

20. Lodeiro, C.; Bastida, R.; Bertolo, E.; Macias, A.; Rodriguez, A.; Polyhedron 2003, 22, 1701.

21. Prabhakaran, R.; Karvembu, R.; Hashimoto, T.; Shimizu, K.; Natarajan, K.; Inorg. Chim. Acta 2005, 358, 2093.

22. Tamizh, M. M.; Mereiter, K.; Kirchner, K.; Bhat, B. R.; Karvembu, R.; Polyhedron 2009, 28, 2157.

23. Motswainyana, W. M.; Onani, M. O.; Ojwach, S. O.; Omondi, B.; Inorg. Chim. Acta 2012, 391, 93.

Submitted: June 30, 2016 Published online: August 3, 2016 